\title{
Total Polyphenol, Flavonoid and Other Bioactive Materials in Different Asparagus Cultivars
}

\author{
Mária TAKÁCS-HÁJOS ${ }^{1^{*}}$, László ZSOMBIK² \\ ${ }^{1}$ University of Debrecen, Faculty of Agricultural and Food Science and Environmental Management, Institute of Horticulture, \\ 138 Böszörményi Str, Debrecen, H-4032,Hungary; hajos@agr.unideb.hu (*correspondingauthor) \\ ${ }^{2}$ University of Debrecen, Centre of Agricultural Science Research Institute, Nyirregyháza, H-4400, Hungary; nykutato@agr.unideb.hu
}

\begin{abstract}
The favourable active ingredient composition of numerous vegetables is published frequently; however its value is often influenced by the variety and the given production year. In the current experiment the main aim was to determinate the bioactive materials (total polyphenol, flavonoid, vitamin C, sulphate-S, protein, nitrate-ion) of blanched (white) asparagus for three widely known varieties ('Cumulus', 'Vitalin', 'Grolim'), grown on mouldy brown sandy soil, in 3 consecutive years (20122014). A significant difference has been found among the varieties in the average of the observed data. 'Vitalin' was prominent with its high total polyphenol $(35.16 \mathrm{mg} / 100 \mathrm{~g})$, vitamin C (59.34 mg/100 g) and flavonoid $(0.52 \mathrm{mg} / 100 \mathrm{~g})$ content. High sulphate-S content - which is characteristic for asparagus - has been measured in the case of 'Cumulus' (287.77 mg/100 g), together with the highest protein content $(2.23 \%)$. The vitamin $\mathrm{C}$ content of the spears is significantly influenced by the production year, therefore higher temperature fluctuations had a negative effect on it, which resulted in its value reducing to one-tenth of the best years in some cases $(89.06 \mathrm{mg} / 100 \mathrm{~g})$. Additionally, it has been found that white asparagus develops under etiolated circumstances, it is not inclined to nitrate accumulation, which is well represented by the values under 20 $\mathrm{mg} / \mathrm{kg}$. Selecting the proper cultivar is important for raw asparagus extract production, which can be produced only of raw materials rich in bioactive materials (including high sulphur content). In this regard 'Vitalin' and 'Cumulus' seemed to be the most advantageous choices.
\end{abstract}

Keywords: Asparagus officinalis, bioactive substances, production year, varieties

\section{Introduction}

Asparagus is more and more popular amongst consumers; this can be explained with its high amount of bioactive components - crude protein (32.69\%), fiber (18.5\%) and carbohydrates $(34.67 \%)$ in dry matter content (10.7\%). Among the mineral elements, were measured in dry matter content K (10.94 mg/100 g), Na (1.84 mg/100 g), Ca (0.67 $\mathrm{mg} / 100 \mathrm{~g}), \mathrm{Fe}(0.19 \mathrm{mg} / 100 \mathrm{~g})$ and $\mathrm{Zn}(2.6 \mathrm{mg} / 100 \mathrm{~g})$ by Aberoumand (2009). This vegetable species is rich in phytochemicals among which flavonoids are the most important. These compounds have positive biological and pharmacological effects on human health (Hartung, 1990), therefore they reduce cholesterol level in the human body and inhibit the development of cancer (Rodríguez et al., 2005; Shao et al., 1996). Total polyphenol content has a close connection with the capability of DPPH free radical scavenging (Maeda et al., 2005). Thus, this compound is suitable for characterising the free radical scavenging capability of asparagus.

The difference amongst varieties is significant in terms of active ingredients, e.g. total polyphenol, radical absorbing activity, which is highly affected by the colour of the spears (etiolated or white, green or purple). The highest values have been measured for green and purple types (Maeda et al., 2005). The higher bioactive ingredient content of floral components which developed in light is verified by celeriac experiments, according to which the total polyphenol and flavonoid content was three and six times higher in the leaves than in the tubers. The polyphenol contents of etiolate part of celeriac (tuber) was 60-90 mg GAE/100 g fresh weight (FW). For the flavonoids was measured $12-17 \mathrm{mg} \mathrm{CE} / 100 \mathrm{~g}$ FW. According the leaves 3-fold difference was detected for polyphenols, while the ratio was 7-8 times more for flavonoids (Takács-Hájos and Borbély-Varga, 2014).

Measurements showed that asparagus had one of the highest antioxidant activities amongst 43 analysed plant species (Tsushida et al., 1994). Also, the antioxidant activity of the asparagus extract is higher than that of broccoli and it showed a close linear relation with the flavonoid content. Thus, flavonoids belong to the most important antioxidant compounds; in the case of asparagus and broccoli its measurement was most suitable with the use of methanol 
60

extract (Sun et al., 2007). In the case of asparagus, rutin is the most important of such compounds (Tsushida et al., 1994); its amount has been determined for $286.5 \pm 6.0 \mathrm{mg} / \mathrm{kg}$ fresh weight (Makris and Rossiter, 2001). Sun and coworkers (2007) calculated the total phenolics content, as 4.9-5.0 $\mathrm{mgCE} / \mathrm{g}$ dry weight, and the amount of flavonoid was 4.7 $\mathrm{mg} / \mathrm{g}$ dry weight.

The antioxidant status of raw asparagus (bioactive compounds, antioxidant activities) is affected by the date of harvest and the utilised part of the spear. More advantageous values have been measured during the $6^{\text {th }}$ week of the harvest period and for the upper third of the spear. Polyphenol (6.54 mg GAE/100 g), flavon (1.73 mg Ce/100 g), vitamin C $(11.09 \mathrm{mg} / 100 \mathrm{~g})$ content were also determined by Lee $e t \mathrm{al}$. (2014).

Quality of asparagus is not only characterised by its bioactive ingredients, but by some quality deteriorating parameters as well. Such a parameter is nitrate content, which is one of the most important non-protein $\mathrm{N}$-component. Its amount is usually higher in the case of etiolated white asparagus than in the green type (Makus, 1995). Excessive Nsupply increases its accumulation.

The amount of sulphate-S is high in asparagus; its advantageous effect is verified by its skin regenerating capability. There is a significant difference in terms of sulphate-S amongst the varieties; its value might fluctuate between 350-833 $\mu \mathrm{g} / \mathrm{g}$ (Shalaby et al., 2002).

It is a well-known fact that sulphur content is significantly influenced by the amount of sulphur absorbable from the soil. Consequently, its amount is lower in the case of plants grown on loose sandy soils in comparison with other soil types with higher sulphur content (Schnug and Haneklaus, 1998). The decrease of sulphur supply of the soil results in the reduction of S-containing secondary metabolic products, e.g. glutathione. Presumably this is the explanation for the higher amount of this compound in asparagus $(4 \mathrm{mg} / \mathrm{g}$ dry $\mathrm{m}$ ) in comparison with other vegetables - broccoli: $0.7 \mathrm{mg} / \mathrm{g}$, spinach: $0.7 \mathrm{mg} / \mathrm{g}$, tomato: $1.9 \mathrm{mg} / \mathrm{g}$ (Pressman, 1997). Besides, it is also presumable that the sulphur containing secondary metabolic products of asparagus have an important role in the development of flavours as well (Holberg et al., 1999).

The environmental potentials of the production site significantly influence the development of the bioactive materials of asparagus.

The aim of the experiment was to measure the bioactive materials of the etiolated asparagus spears and determined the differences depending on the varieties and production years. Additionally, the intention was to find out which genotype shows the most stable nutritional parameters under the climatic and soil conditions of the given production district.

Explanation is sought for the changes of temperature values of the harvest period and the compounds causing antioxidant effect (polyphenols, flavonoids, vitamin C, sulphate-S).

\section{Materials and methods}

The trial has been carried out between 2012 and 2014 at the Trial site at Pallag of the Centre of Agricultural Science of the University of Debrecen. The soil of the production site is humous brown sand; the soil analysis data are shown in Table 1.
Table 1. Soil analysis data

\begin{tabular}{lc}
\hline Analysed parameter (unit of measure) & Amount \\
\hline $\mathrm{pH}(\mathrm{KCl})$ & 6.64 \\
$\mathrm{pH}$ & 6.86 \\
Plasticity index of Arany $\mathrm{K}_{\mathrm{A}}$ & 27 \\
Total water soluble salt\% $(\mathrm{m} / \mathrm{m})$ & 0.017 \\
$\mathrm{CaCO}_{3} \%(\mathrm{~m} / \mathrm{m})$ & 2.555 \\
$\mathrm{Humus}^{2}(\mathrm{~m} / \mathrm{m})$ & 1.74 \\
$\mathrm{AL}$ - soluble $\mathrm{P}_{2} \mathrm{O}_{5}(\mathrm{mg} / \mathrm{kg})$ & 534.1 \\
$\mathrm{AL}$ - soluble $\mathrm{K}_{2} \mathrm{O}(\mathrm{mg} / \mathrm{kg})$ & 592.5 \\
$\mathrm{KCl}$ - soluble $\mathrm{NO}_{3}^{-}+\mathrm{NO}_{2}-$ - Nitrogen $(\mathrm{mg} / \mathrm{kg})$ & 45.55 \\
$\mathrm{AL}$ - soluble $\mathrm{Na}_{(\mathrm{mg} / \mathrm{kg})}$ & 22.35 \\
$\mathrm{KCl}$ - soluble $\mathrm{Mg}_{(\mathrm{mg} / \mathrm{kg})}$ & 164.2 \\
$\mathrm{KCl}$ - soluble $\mathrm{SO}_{4}{ }^{2-}-\mathrm{sulphur}(\mathrm{mg} / \mathrm{kg})$ & 13.81 \\
\hline
\end{tabular}

For the production of white (etiolated) asparagus ridge cultivation has been used.

On the basis of the soil analysis data it was clear that the $\mathrm{pH}$ of the soil was mildly acidic, which has a positive effect on the mobilisation of nutritive elements. Humus content was $1.74 \%$, which is suitable for asparagus production. The supply of phosphorus and potassium were adequate, the nitrate content was $45.55 \mathrm{mg} / \mathrm{kg}$. The sulphur-S content of the soil was 13.81 $\mathrm{mg} / \mathrm{kg}$. The Na content was acceptable $(22.35 \mathrm{mg} / \mathrm{kg}), \mathrm{Mg}$ content was good $(164.2 \mathrm{mg} / \mathrm{kg})$.

The daily mean temperature in respect of the harvesting period of asparagus is shown in Fig. 1.

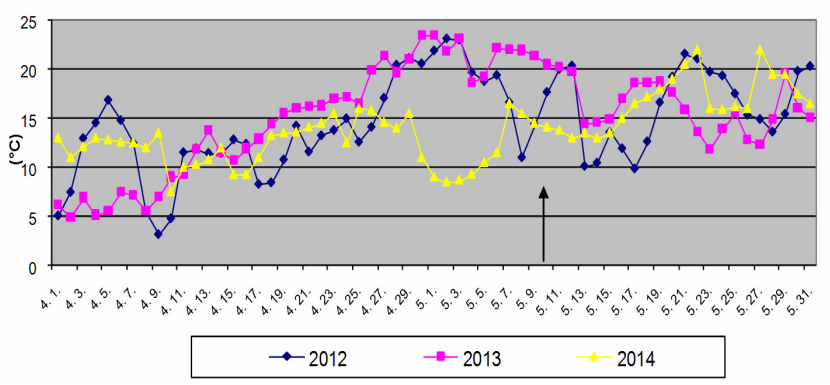

Fig. 1. Mean temperature values, Debrecen, Pallag, 2012-2014

It could be established that temperature was more or less even in 2014, while there were major fluctuations in 2012. The average of the mean temperatures of the period between early April and the sampling date ( $9^{\text {th }}$ May every year) was $13.82 \pm$ $5.19^{\circ} \mathrm{C}$ in $2012,14.56 \pm 6.15^{\circ} \mathrm{C}$ in 2013 , while it was lower but more even in $2014\left(12.16 \pm 2.37^{\circ} \mathrm{C}\right)$.

The change of different bioactive materials has been evaluated through the measurements depending on the varieties and the production year. Three varieties have been observed ('Cumulus', 'Vitalin', 'Grolim') for three years (2012-2014). Sampling took place in the middle of the harvest period ( $9^{\text {th }}$ May every year).

The measurements have been carried out on the basis of three repetitions $(0.5 \mathrm{~kg})$ of fresh asparagus spears, in the Central Laboratory of the University of Debrecen, Centre of Agricultural Science. For the evaluation of the measurement data, two-factor analysis of variance has been applied.

The analytical measurements involved the following bioactive materials:

Total polyphenols (mg GAE/100 g fresh product) were determined by Folin Ciocalteu colorimetric method, results were given in gallic acid equivalent value. 
- Flavonoid content (mg CE/100 g fresh product) was determined using colorimetric method (Lamaison and Carnat, 1990), results were given in catechin equivalent value.

- Vitamin C content (mg/100 g) was determined by redox titration using iodine solution.

- Dry material (\%) content was measured by drying in oven at $105^{\circ} \mathrm{C}$.

- Protein content (\%) was calculated on basis of the total nitrogen content using the following formula: Total $\mathrm{N}$ content $(\%) \times 6.25=$ total protein content $(\%)$

- The nitrogen content was measured by Kjeldahl method.

Sulphate-S and nitrate ion content $(\mathrm{mg} / \mathrm{kg})$ were determined colorimetrically, according to Novozamsky et al. (1986) and Kücke and Schnug (1996).

\section{Results and discussions}

Total polyphenol content has been evaluated for three varieties during 2 years of the experiment. A significant difference was found between the observed years in terms of the variety average; the data is shown in Table 2.

Table 2. Total polyphenol (mg GAE/100 g fresh product) by varieties and production years

\begin{tabular}{lccc}
\hline Variety/year & 2013 & 2014 & $\begin{array}{c}\text { Year average } \\
\text { Signif. at } \mathrm{P}= \\
0.05\end{array}$ \\
\hline Cumulus & $30.97 \mathrm{a}$ & $36.6 \mathrm{a}$ & $33.79 \mathrm{a}$ \\
Vitalin & $30.47 \mathrm{a}$ & $39.85 \mathrm{~b}$ & $35.16 \mathrm{~b}$ \\
Grolim & $30.97 \mathrm{a}$ & $32.64 \mathrm{c}$ & $31.81 \mathrm{c}$ \\
Variety average & & $36.36 \mathrm{~b}$ & \\
$\begin{array}{l}\text { Significant at } \mathrm{P}= \\
0.05\end{array}$ & $30.80 \mathrm{a}$ & & \\
\hline
\end{tabular}

The lower, but more even, temperature values of 2014 $\left(12.16 \pm 2.37{ }^{\circ} \mathrm{C}\right)$ had a positive effect on the total polyphenol amount during the pre-harvest period (35.36 $\mathrm{mg} / 100 \mathrm{~g})$. In 2013 this value was lower $(30.86 \mathrm{mg} / 100 \mathrm{~g})$, when spring was warmer, but temperature fluctuations have also been larger $\left(14.56 \pm 6.15^{\circ} \mathrm{C}\right)$.

In terms of variety average, 'Vitalin' presented the highest total polyphenol content $(35.16 \mathrm{mg} / 100 \mathrm{~g})$. In 2014, this value reached nearly $40 \mathrm{mg} / 100 \mathrm{~g}$. In the $10 \%$ dry weight samples, a bit higher amount (4.9-6.4 mg/CE/g DW) were determined by Sun et al. (2007) and Lee et al. (2014).

Regarding the flavonoid analysis, the temperature values of 2014 showed their positive effects on the synthesis of these secondary metabolic products as well. $0.75 \mathrm{mg} / 100 \mathrm{~g}$ has been measured as a variety average for this compound (Table 3 ).

Table 3. Flavonoid (mg CE/100 g fresh product) content by varieties and production years

\begin{tabular}{lccc}
\hline \multicolumn{1}{c}{ Variety/year } & 2013 & 2014 & $\begin{array}{c}\text { Year average } \\
\text { Signif. at } \mathrm{P}= \\
0.05\end{array}$ \\
\hline $\begin{array}{l}\text { 'Cumulus' } \\
\text { 'Vitalin' }\end{array}$ & $0.11 \mathrm{a}$ & $0.84 \mathrm{a}$ & $0.48 \mathrm{a}$ \\
'Grolim' & $0.11 \mathrm{a}$ & $0.93 \mathrm{a}$ & $0.52 \mathrm{a}$ \\
$\begin{array}{l}\text { Variety average } \\
\text { Significant at } \mathrm{P}=\end{array}$ & $0.17 \mathrm{a}$ & $0.47 \mathrm{~b}$ & $0.32 \mathrm{~b}$ \\
0.05 & $0.13 \mathrm{a}$ & $0.75 \mathrm{~b}$ & \\
\hline
\end{tabular}

Similar values have been measured in the case of 'Vitalin' and 'Cumulus' in terms of the average of the observation years $(0.52$ and $0.48 \mathrm{mg} / 100 \mathrm{~g})$, while 'Grolim' represented lower values $(0.32 \mathrm{mg} / 100 \mathrm{~g})$.

Juice extracted from raw asparagus has a significant curative effect; therefore its vitamin $\mathrm{C}$ content is also an important factor for its application. On the basis of the measurements of three years (Table 4) it has been found that the largest value has been measured in 2013 (89.06 $\mathrm{mg} / 100 \mathrm{~g}$ ), while in 2014 it was $64.27 \mathrm{mg} / 100 \mathrm{~g}$ as variety average.

Table 4. Vitamin C (mg/100 g) content by varieties and production year

\begin{tabular}{lcccc}
\hline Variety/year & 2012 & 2013 & 2014 & $\begin{array}{c}\text { Year average } \\
\text { Signif. at } \mathrm{P}= \\
0.05\end{array}$ \\
\hline 'Cumulus' & $9.03 \mathrm{a}$ & $91.83 \mathrm{a}$ & $62.22 \mathrm{a}$ & $54.36 \mathrm{a}$ \\
'Vitalin' & $11.7 \mathrm{a}$ & $88.83 \mathrm{~b}$ & $77.5 \mathrm{~b}$ & $59.34 \mathrm{~b}$ \\
'Grolim' & $8.14 \mathrm{a}$ & $86.53 \mathrm{~b}$ & $53.08 \mathrm{c}$ & $49.25 \mathrm{c}$ \\
$\begin{array}{l}\text { Variety } \\
\text { average }\end{array}$ & & & & \\
$\begin{array}{l}\text { Significant } \\
\text { at } \mathrm{P}=0.05\end{array}$ & $9.62 \mathrm{a}$ & $89.06 \mathrm{~b}$ & $64.27 \mathrm{c}$ & \\
\hline
\end{tabular}

Table 5. Sulphate- $\mathrm{S}(\mathrm{mg} / \mathrm{kg})$ content by varieties and production years

\begin{tabular}{lcccc}
\hline Variety/year & 2012 & 2013 & 2014 & $\begin{array}{c}\text { Year } \\
\text { average } \\
\text { Signif. at } \\
\mathrm{P}=0.05\end{array}$ \\
\hline 'Cumulus' & $279.3 \mathrm{a}$ & $279 \mathrm{a}$ & $305 \mathrm{ab}$ & $287.77 \mathrm{a}$ \\
'Vitalin' & $225 \mathrm{~b}$ & $284.3 \mathrm{a}$ & $320.33 \mathrm{a}$ & $276.54 \mathrm{a}$ \\
'Grolim' & $211.67 \mathrm{~b}$ & $275 \mathrm{a}$ & $283 \mathrm{~b}$ & $256.56 \mathrm{~b}$ \\
Variety & & & & \\
$\begin{array}{l}\text { average } \\
\text { Significant at }\end{array}$ & $238.66 \mathrm{a}$ & $279.43 \mathrm{~b}$ & $302.78 \mathrm{c}$ & \\
$\mathrm{P}=0.05$ & & & & \\
\hline
\end{tabular}

The order of the varieties was similar during the years of observation in terms of this parameter as well. 'Vitalin' was prominent with its average value of $59.38 \mathrm{mg} / 100 \mathrm{~g}$, while 'Grolim' provide the lowest amount $(49.25 \mathrm{mg} / 100 \mathrm{~g})$.

Observing the effect of production year, it is clear that in 2012 the amount of vitamin $\mathrm{C}$ was one-tenth of the amount measured in 2013. This means that the level of this compound is highly dependent on climatic factors. In 2012, pre-harvest period was characterised by significant temperature fluctuations (Fig. 1). According to $10 \%$ dry weight, the vitamin $\mathrm{C}$ content was lower than the amount (11.09 mg/100 g) measured by Lee et al. (2014).

Sulphur has an important role in the change of the secondary metabolic products of asparagus, which is an important component of glutathione besides other Scontaining compounds. The measurement of the sulphate-S content showed that the effect of the production year was significant. In 2014, a significantly higher value has been measured as variety average $(302.78 \mathrm{mg} / \mathrm{kg})$, than in the previous 2 years (Table 5). The lowest sulphate-S level was found in 2012 (238.66 mg/kg). 'Cumulus' and 'Vitalin' showed favourable values (287.77 and $276.54 \mathrm{mg} / \mathrm{kg}$ ). 'Grolim' fell behind in this respect as well.

According to the relevant literature, the value of protein in asparagus is approx. 2\% (Shalaby et al., 2002). In spite of this, the protein content can rich more than $3 \%$ in the fresh 
62

wild asparagus stem (Aberoumand, 2009). According to the current study measurements, this compound changed between 1.75 and $2.00 \%$ during the different observation years (Table 6). In 2012, low amounts have been measured for this parameter. As variety average, the highest amount was measured for 'Cumulus' (2.23\%), which repeated in almost every year. The year 2012 reduced sulphate-S content in the plants, resulting in reduced protein synthesis as well. However, 'Cumulus' provided large amounts even in this year (2.26\%).

Table 6. Protein (\%) content by varieties and production years

\begin{tabular}{lcccc}
\hline Variety/year & 2012 & 2013 & 2014 & $\begin{array}{c}\text { Year average } \\
\text { Signif. at } \mathrm{P} \\
=0.05\end{array}$ \\
\hline 'Cumulus' & $2.26 \mathrm{a}$ & $2.03 \mathrm{a}$ & $2.41 \mathrm{a}$ & $2.23 \mathrm{a}$ \\
'Vitalin' & $1.57 \mathrm{~b}$ & $2.07 \mathrm{a}$ & $1.68 \mathrm{~b}$ & $1.77 \mathrm{~b}$ \\
'Grolim' & $1.43 \mathrm{~b}$ & $1.89 \mathrm{a}$ & $1.9 \mathrm{~b}$ & $1.74 \mathrm{~b}$ \\
$\begin{array}{l}\text { Variety } \\
\text { average }\end{array}$ & $1.75 \mathrm{a}$ & $2.00 \mathrm{~b}$ & $2.00 \mathrm{~b}$ & \\
$\begin{array}{l}\text { Significant } \\
\text { at } \mathrm{P}=0.05\end{array}$ & & & & \\
\hline
\end{tabular}

Consequently, protein accumulation in asparagus spears is determined not only by environmental factors, but genotype as well.

Besides bioactive materials, quality deteriorating parameters were also examined during variety evaluation. Such a parameter is the nitrate content of the spears. According to the measurements, the climatic conditions of 2012 supported the absorption of nitrate into the asparagus spears. The amount of nitrate in $2012(15.93 \mathrm{mg} / \mathrm{kg})$ was multiple of the amounts measured in the rest of the years (3.68 and $7.25 \mathrm{mg} / \mathrm{kg}$ ) as variety average (Table 7), but it was still far below the allowed nitrate threshold $(200 \mathrm{mg} / \mathrm{kg}$ for baby food).

In terms of year average, larger amounts $(11.70 \mathrm{mg} / \mathrm{kg})$ have been measured for 'Vitalin', which is a vigorous, highyield variety.

Table 7. Nitrate ion $(\mathrm{mg} / \mathrm{kg})$ content by years and production years

\begin{tabular}{lcccc}
\hline Variety/year & 2012 & 2013 & 2014 & $\begin{array}{c}\text { Year } \\
\text { average } \\
\text { Signif. at } \\
\mathrm{P}=0.05\end{array}$ \\
\hline 'Cumulus' & $16.81 \mathrm{a}$ & $5.28 \mathrm{a}$ & $4.71 \mathrm{a}$ & $8.93 \mathrm{a}$ \\
'Vitalin' & $22.70 \mathrm{~b}$ & $3.39 \mathrm{a}$ & $9.02 \mathrm{a}$ & $11.70 \mathrm{~b}$ \\
'Grolim' & $8.27 \mathrm{c}$ & $2.38 \mathrm{a}$ & $8.01 \mathrm{a}$ & $6.22 \mathrm{a}$ \\
$\begin{array}{l}\text { Variety } \\
\text { average }\end{array}$ & $15.93 \mathrm{a}$ & $3.68 \mathrm{~b}$ & $7.25 \mathrm{c}$ & \\
$\begin{array}{l}\text { Significant at } \\
\mathrm{P}=0.05\end{array}$ & & & & \\
\hline
\end{tabular}

\section{Conclusions}

The antioxidant effect of asparagus spears can be well characterised by the total polyphenol, flavonoid, vitamin C and sulphate-S content. A significant difference was detected amongst varieties in the average data of the 3 years. 'Vitalin' was prominent with its higher total polyphenol (35.16 $\mathrm{mg} / 100 \mathrm{~g})$, vitamin C (59.34 mg/100 g) and flavonoid (0.52 $\mathrm{mg} / 100 \mathrm{~g}$ ) content. Higher sulphate-S content (287.77 $\mathrm{mg} / \mathrm{kg}$ ) and protein amount $(2.23 \%)$ has been measured for 'Cumulus'. The examination of the production year effect showed that the climatic conditions of 2012 had an unfavourable effect on the vitamin $\mathrm{C}$ content of the asparagus spears, which was in some cases one-tenth of the data measured in the next two years $(89.06 \mathrm{mg} / 100 \mathrm{~g})$. Under the current study production circumstances the nitrate content of asparagus remained far below the threshold (3.68-15.93 $\mathrm{mg} / \mathrm{kg}$ ) in the variety average. Sulphate-S content has a special importance in the synthesis of glutathione, and consequently in the nutrition-physiological significance of asparagus. It was determined between 238.66 and $302.78 \mathrm{mg} / \mathrm{kg}$ as variety average. In this respect, 'Vitalin' and 'Cumulus' were prominent with their values of 320.33 and $305 \mathrm{mg} / \mathrm{kg}$. Thus, the selection of the proper starting material is essential for the production of raw asparagus extract. According to our experiment results 'Cumulus' and 'Vitalin' have been the most favourable in this regard. Production year, especially by mean temperature have a significant effect on the nutritional values of asparagus.

\section{References}

Aberoumand A (2009). Proximate and mineral composition of the Marchhubeb (Asparagus officinalis) in Iran. World Journal of Dairy and Food Sciences 4(2): 145-149.

Hartung AC, Nair MG, Putnam AR (1990). Isolation and characterisation of phytotixic compounds from asparagus (Asparagus officinalis L.) roots. J Chem Ecol 16(5):1707-1718.

Holberg E, Ulrich D, Standhardt D, Kecke S (1999). Evaluation of Asparagus officinalis L. flavour quality for breeding purposes. Acta Hort 479:135-142.

Kücke M, Schnug E (1996). Advantages of nitrate determination by use of E. coli cells in different matrices. Communications in Soil Scienceand Plant Analysis 27(5-8):977-991.

Lamaison L, Carnat A (1990). Teneurs en acide rosmarinique, en dérivés hydroxycinnamiques totaux et activités antioxydantes chez les Apiacées, les Borraginacées et les Lamiacées médicinales. Pharm Acta Helv 65:315-320.

Lee JW, Lee JH, Yo IH, Gorinstein S, Bae JH, Ku YG (2014). Bioactive compounds, antioxidant and binding activities and spear yield of Asparagus officinalis L. Plant Foods for Human Nutrition 69(2):175-181.

Maeda T, Kakuta H, Sonoda T, Motoki S, Ueno R, Suzuki T, Oosawa K (2005). Antioxidation capacities of extracts from green, purple and white asparagus spears related to polyphenol concentration. HortScience 40(5):1221-1224.

Makus DJ (1995). Response in green and white asparagus to supplemental nitrogen and harvest date. HortScience 30(1):55-58.

Makris DP, Rossiter JT (2001). Domestic processing of onion bulbs (Allium cepa) and asparagus spears (Asparagus officinalis): effect on flavonol content and antioxidant status. Journal of Agricultural and Food Chemistry 49(7):32163222. 
Novozamsky I, Van Eck R, Van der Lee JJ, Houba VJG, Temminghoff E (1986). Determination of total sulphur and extractable sulphate in plant materials by inductively-coupled plasma atomic emission spectrometry. Communications in Soil Science and Plant Analysis 17(11):1147-1157.

Pressman AH (1997). The GSH phenomenon: nature's most powerful antioxidant and healing agent: Glutathione. St. Martin's Press, New York, 228 p.

Rodríguez R, Jaramillo S, Rodríguez G, Espejo JA, Guillén R, Fernández-Bolaños J, Heredia A, Jiménez A (2005). Antioxidant activity of ethanolic extracts from several asparagus cultivars. Journal of Agricultural and Food Chemistry 53(13):5212-5217.

Schnug E, Haneklaus S (1998). Diagnosis of sulphur nutrition, pp 1-38. In: Schnug E, Beringer H (Eds). Sulphur in AgroEcosystems. Vol. 2 of the series 'Mineral Nutrition in Ecosystems', Kluwer Academic Publ, Dordrecht, Netherland.

Shalaby T, Sator C, Haneklaus S, Schnug E (2004). Influence of Variety and Cultivation on Mineral Elements and Protein Content of Asparagus (Asparagus officinalis L.). Acta Hort 629:313-319.
Shao Y, Chin CK, Ho CT, Ma W, Garrison SA, Huang MT (1996). Anti-tumor activity of the crude saponins obtained from asparagus. Cancer Letters 104(1):31-36.

Sun T, Powers JR, Tang J (2007). Evaluation of the antioxidant activity of asparagus, broccoli and their juices. Food Chemistry 105(1):101-106.

Takács-Hájos M, Borbély-Varga M (2014). Formation of bioactive compounds of celery (Apium graveolens L. convar. rapaceum) on the effect of the growing method. European Chemical Bulletin 3(6):605-608.

Tsushida T, Suzuki M, Kurogi M (1994). Evaluation of antioxidant activity of vegetable extracts and determination of some active compounds. J Jap Soc Food Sci Tech 41(9):611618. 